\title{
Discordant end of induction bone marrow morphology and flow cytometry in a paediatric patient with acute myeloid leukaemia
}

\author{
Breanna Breeding, Kelly Ann Bush, Dennis John Kuo
}

Division of Pediatric Hematology-Oncology, University of California San Diego, School of Medicine, La Jolla, California, USA

\section{Correspondence to} Dr Dennis John Kuo; dekuo@ucsd.edu

Accepted 16 December 2021

\section{DESCRIPTION}

The patient was a 5-year-old boy with newly diagnosed acute myeloid leukaemia (AML) who completed induction 1 chemotherapy on Children's Oncology Group (COG) study AAML1831 arm B with liposomal daunorubicin and cytarabine, and gemtuzumab ozogamicin. Having had a clinically uncomplicated course, on day 31 of cycle 1 he underwent bone marrow aspiration and biopsy with minimal residual disease (MRD) by flow cytometry to assess the response. Peripheral counts recovered after nadir, with an absolute neutrophil count of 341 on day 31 . We were notified by pathology several hours after the procedure that his bone marrow aspiration was concerning for 33\% myeloid blasts by morphology (figures 1 and 2). This was significantly higher than the $23 \%$ blasts seen by morphology at diagnosis and therefore raised concerns for induction failure. Given the apparent lack of response, and our desire to be fully transparent with the family, the treating team reported these results to the parents as soon as they were available, while still awaiting MRD results. During that time plans for an immediate continuation into induction 2 with plans for eventual haematopoietic stem cell transplant were also discussed, which greatly distressed the grieving family. The flow cytometry MRD results returned 3 days later, and no blasts were detected at the threshold of the test $(<0.02 \%)$. While these results were a great relief to the appreciative family, it was a harrowing 3 days of grief and anxiety. The patient ultimately completed AML chemotherapy and all subsequent

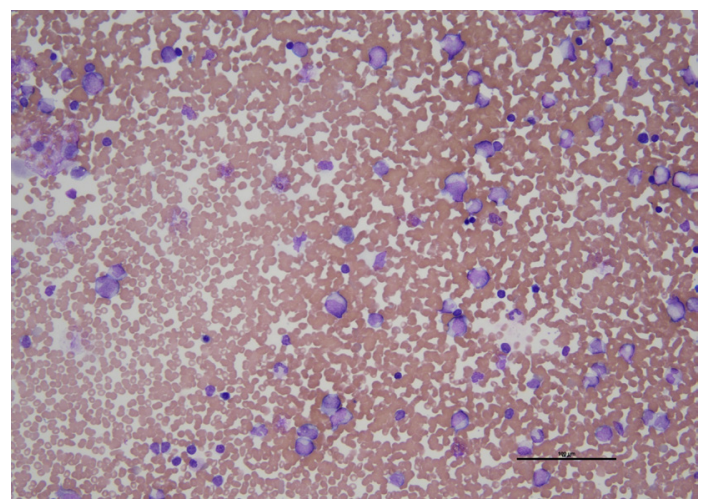

Figure 1 Bone marrow aspiration smear at 200x showing many immature cells concerning for blasts in a background of normal trilineage maturing haematopoietic cells.

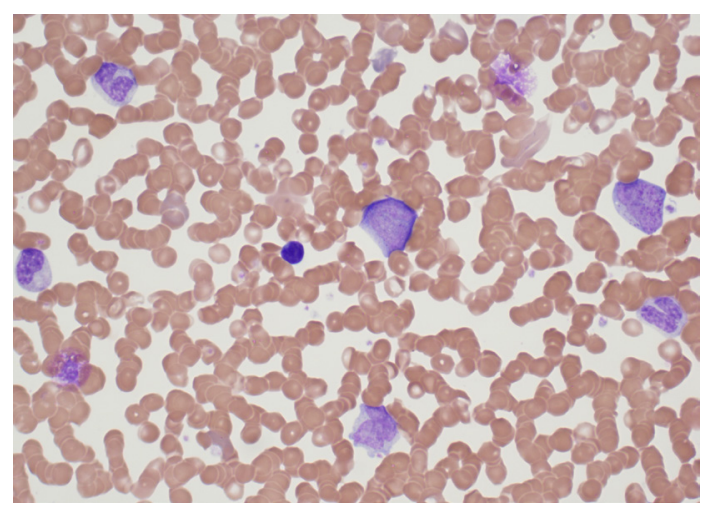

Figure 2 Bone marrow aspiration smear at $600 x$ showing the morphology of immature cells concerning for blasts.

bone marrow evaluations have remained negative by both morphological examination and MRD flow cytometry.

It can be difficult to distinguish leukaemic myeloblasts from benign immature cells in a recovering bone marrow by morphology alone, and the traditional morphological blast percentage of 5\% defining remission may be too imprecise when compared with simultaneously performed flow cytometry MRD testing. In a COG report of 12 patients with refractory disease $(>20 \%$ blasts) by morphological evaluation, 1 patient $(8 \%)$ had no evidence of disease by flow cytometry. ${ }^{1}$ A report from St Jude's Children's Research Hospital demonstrated that flow cytometry was markedly superior to morphological review in detecting residual leukaemic disease and in predicting outcome. ${ }^{2}$ Of the 1215 samples in remission by morphology (<5\% myeloblasts), $8.2 \%$ were MRD positive $(\geq 0.1 \%)$ by flow cytometry. More surprisingly though, $57.5 \%$ of the 167 bone marrow samples that were not in remission by morphology $(\geq 5 \%$

\section{Patient's perspective}

Hearing that the chemo didn't work was far worse news than receiving the original diagnosis. We were in utter despair. Getting the news a few days later that the MRD was negative was thrilling, but we were left with an uneasy feeling of mistrust in our doctors and the treatment. Luckily we had a meeting with the team and were able to resolve and repair the negative feelings. - Patient's mother 


\section{Learning points}

- Distinguishing malignant leukaemic blasts from benign immature cells in a recovering bone marrow in AML at the end of induction 1 chemotherapy by morphology alone is challenging.

- Flow cytometry-based minimal residual disease (MRD) testing performs better than morphological review in assessing response to chemotherapy in AML and predicting treatment outcome.

- Even patients who appear not to be in remission by morphology at the end of induction may be MRD negative by flow cytometry.

blasts) were MRD negative by flow cytometry. In this study, outcomes were most highly correlated with flow cytometry MRD results. By contrast, morphological remission after induction 1 was not associated with better survival. If flow cytometry MRD testing is the gold standard for determining remission, morphological review produces significant percentages of false positives and false negatives and is a poor predictor of survival. Conveying the knowledge of the imprecision of morphology as a measure of treatment response to the family, even when discussing the apparently concerning morphological findings, could have avoided significant unnecessary distress while they awaited the flow cytometry MRD results.

Contributors All the authors (BB, KAB, DJK) have contributed to the design, writing, editing and submission of this manuscript in significant ways and have agreed upon the content of this manuscript.

Funding The authors have not declared a specific grant for this research from any funding agency in the public, commercial or not-for-profit sectors.

Competing interests None declared.

Patient consent for publication Consent obtained from parent(s)/guardian(s).

Provenance and peer review Not commissioned; externally peer reviewed.

Case reports provide a valuable learning resource for the scientific community and can indicate areas of interest for future research. They should not be used in isolation to guide treatment choices or public health policy.

\section{ORCID iD}

Dennis John Kuo http://orcid.org/0000-0003-4154-0057

\section{REFERENCES}

1 Loken MR, Alonzo TA, Pardo L, et al. Residual disease detected by multidimensional flow cytometry signifies high relapse risk in patients with de novo acute myeloid leukemia: a report from children's Oncology Group. Blood 2012;120:1581-8.

2 Inaba H, Coustan-Smith $\mathrm{E}, \mathrm{Cao} \mathrm{X}$, et al. Comparative analysis of different approaches to measure treatment response in acute myeloid leukemia. J Clin Oncol 2012;30:3625-32

Copyright 2021 BMJ Publishing Group. All rights reserved. For permission to reuse any of this content visit https://www.bmj.com/company/products-services/rights-and-licensing/permissions/

BMJ Case Report Fellows may re-use this article for personal use and teaching without any further permission.

Become a Fellow of BMJ Case Reports today and you can:

- Submit as many cases as you like

- Enjoy fast sympathetic peer review and rapid publication of accepted articles

- Access all the published articles

Re-use any of the published material for personal use and teaching without further permission

Customer Service

If you have any further queries about your subscription, please contact our customer services team on +44 (0) 2071111105 or via email at support@bmj.com.

Visit casereports.bmj.com for more articles like this and to become a Fellow 